\title{
FORAGE YIELD AND QUALITY DIFFERENCES OF AUTUMN AND SPRING-SOWN FORAGE PEA GENOTYPES UNDER CENTRAL ANATOLIA CONDITIONS
}

\author{
Onur ILERI*, Suleyman AVCI, Ali KOC \\ Eskisehir Osmangazi University, Faculty of Agriculture, Department of Field Crops, Eskişehir, TURKEY \\ *Corresponding author: oileri@ogu.edu.tr
}

Received: 20.01.2021

\begin{abstract}
In this study, some common forage pea cultivars (Golyazi, Ozkaynak, Taskent, Tore, and Urunlu) and a population of Ardahan were investigated during 2015 and 2016 years in Eskisehir condition to determine the forage yield and quality parameters. The fresh forage yield of autumn-sown forage pea $\left(24.36 \mathrm{t} \mathrm{ha}^{-1}\right)$ was higher than the spring-sown plants $\left(13.42 \mathrm{t} \mathrm{ha}^{-1}\right)$. Golyazi and Urunlu cultivars had lower fresh forage yields (14.63 and $14.81 \mathrm{t} \mathrm{ha}^{-1}$ respectively) than the other genotypes and Ozkaynak, Taskent, Tore (cvs.), and Ardahan (pop.) were statistically ranked in the same group (between 19.92 and $22.52 \mathrm{t} \mathrm{ha}^{-1}$ ). The genotypes produced more dry matter in autumn than spring. The crude protein was higher at autumn sowing $(\mathbf{2 1 . 1 7 \%})$ than the spring sowing $(\mathbf{1 8 . 3 6 \%})$ and Ozkaynak had the highest value $(\mathbf{2 1 . 5 3 \%})$ while Ardahan population was the lowest $(\mathbf{1 7 . 7 6 \%})$. NDF content was higher in the spring season $(37.62 \%)$ but only the difference between Taskent $(37.60 \%)$ and Golyazi (34.06\%) was significant among the genotypes. Variation in the ADF content was only significant among the genotypes and the difference between Taskent (33.41\%) and Golyazi (31.62\%) was significant only as similar to NDF. As a result, Ozkaynak, Taskent, Tore cultivars produce more yield with a satisfying quality by sowing in autumn at Eskisehir conditions, and the population of Ardahan has a high potential to develop new cultivars suitable for the region.
\end{abstract}

Keywords: Adaptation, Forage pea, Forage quality, Winter Catch Crop, Yield

\section{INTRODUCTION}

It is well known that good quality forage shortage affects animal production negatively in Turkey. Increasing high-quality forage production is one of the possible ways to overcome this problem. The cultivation area of the forage crops constitutes only about $8 \%$ of total arable lands in Turkey (TUIK, 2019) and in present conditions, increasing the rate of the forage crops cultivation area is extremely challenging especially in the central and coastal regions due to high-yielded cash crops cultivation. Therefore, integrating the annual forage crops into the cropping system as winter catch crop or second crop seems to be an alternative to increase the good quality forage production in Turkey, especially in the areas in middle and low altitudes.

Forage pea provides good quality forage for livestock due to its high protein (about 20\%) and lysine contents, digestibility, palatability, and it has also high adaptability to different environmental conditions (Acikgoz, 2001; Cacan et al., 2016; Ates and Tekeli, 2017). Growers approved the forage pea due to its availability as a second crop or winter catch crop and consequently, the sowing area had been increased four times from 2014 to 2019 (TUIK, 2019). The green forage yield of the forage pea could show a variation between 10 and $40 \mathrm{tha}^{-1}$ with about $20-25 \%$ dry matter content depending on the cultivation practices in Turkey (Acikgoz, 2001; Bilgili et al., 2010). Researchers reported various dry matter yields of forage pea as $8.4 \mathrm{tha}$ ${ }^{1}$ in coastal regions (Uzun et al., 2005), $4.2 \mathrm{t} \mathrm{ha}^{-1}$ in Eastern Anatolia (Tan et al., 2014), and $11.9 \mathrm{t} \mathrm{ha}^{-1}$ in Central Anatolia (Konuk and Tamkoc, 2018).

Higher animal performance could be achieved by higher forage quality (Ball et al., 2001). Crude protein, one of the most important quality characteristics, positively affects the growth, milk, and meat yields of the livestock (Ball et al., 2001; Choi et al., 2005; Ghorbani et al., 2010; Atis and Acikalin, 2020). In addition to crude protein, NDF and ADF contents have also significant effects on the milk and meat performances of animals by increasing the dry matter intake (Beauchemin, 1996; Tekce and Gul, 2014). These quality characteristics, therefore should be taken into consideration to evaluate the quality performance of forage pea. Some researchers reported the values of crude protein content between $12.80-18.17 \%$ (Uzun et al., 2005; Tan et al., 2014; Asci et al., 2015), NDF content between 32.33 $48.54 \%$ (Kocer and Albayrak, 2012; Asci et al., 2015) and ADF content between 21.53 - 30.33 (Tan et al., 2013; Yavuz, 2017) for forage pea. 
In Central Anatolia, the period after harvesting of winter cereals to the next autumn sowing season is adequate for the second crop production and forage pea has an important potential both as a second crop after winter cereals harvest and as a winter catch crop before the silage maize cultivation in the region. Different genotypes could show various responses under autumn or spring sowing conditions (Konuk and Tamkoc, 2018) and that plays a deterministic role to select the proper growing season and cultivar in the region.

This experiment aimed to determine the yield performance and the forage quality of different forage pea genotypes as a winter catch crop by sowing in autumn and compare the performance with conventional spring sowing under Eskisehir ecological conditions where semi-arid climate prevails.

\section{MATERIALS AND METHODS}

This study was carried out in the experimental area of the Faculty of Agriculture, Eskisehir Osmangazi University during the 2015 and 2016 years. The experimental area is located at $39^{\circ} 45^{\prime} 20^{\prime \prime} \mathrm{N}$ and $30^{\circ} 28^{\prime} 35^{\prime \prime} \mathrm{E}$ with a typical terrestrial climate characteristic and its altitude is $800 \mathrm{~m}$ above sea level. Precipitation mostly falls in winter as snow and as rain in early spring. Winter temperature averages generally maintain near-zero (Table 1) but could critically decrease below $-10 / 15^{\circ} \mathrm{C}$ for a few days or weeks. The soil analysis report of the Soil Science Department, Faculty of Agriculture indicated that soil characteristics of $0-20 \mathrm{~cm}$ depth were loamy, organic matter and lime contents were $1.9 \%$ and $3.6 \%$ respectively. The content of $\mathrm{K}_{2} \mathrm{O}$ was determined as $407 \mathrm{~kg} \mathrm{ha}^{-1}$ and $\mathrm{P}_{2} \mathrm{O}_{5}$ content was $64 \mathrm{~kg} \mathrm{ha}^{-1}$ according to the Olsen method.

Table 1. Meteorological data related to experimental months

\begin{tabular}{|c|c|c|c|c|c|c|c|c|c|}
\hline \multirow[t]{2}{*}{ Months } & \multicolumn{3}{|c|}{ Precipitation (mm) } & \multicolumn{3}{|c|}{ Temperature $\left({ }^{\circ} \mathrm{C}\right)$} & \multicolumn{3}{|c|}{ Humidity (\%) } \\
\hline & 2014 & 2015 & 2016 & 2014 & 2015 & 2016 & 2014 & 2015 & 2016 \\
\hline January & & 29,9 & 77,6 & & $-0,8$ & 0,0 & & 86,3 & 89,9 \\
\hline February & & 44,8 & 33,6 & & 2,7 & 6,6 & & 77,8 & 76,3 \\
\hline March & & 38,9 & 41,2 & & 5,6 & 7,4 & & 74,8 & 66,7 \\
\hline April & & 26,6 & 36,7 & & 7,9 & 12,9 & & 64,4 & 61,3 \\
\hline May & & 47,8 & 44,7 & & 15,5 & 14,2 & & 64,7 & 69,9 \\
\hline June & & 151,1 & 6,3 & & 17,1 & 20,9 & & 76,5 & 59,2 \\
\hline July & & 0,0 & & & 22,1 & & & 60,3 & \\
\hline August & & 37,2 & & & 22,7 & & & 64,3 & \\
\hline September & & 3,1 & & & 20,9 & & & 63,3 & \\
\hline October & 42,9 & 34,0 & & 12,2 & 13,1 & & 78,9 & 77,1 & \\
\hline November & 15,6 & 8,2 & & 6,3 & 7,9 & & 80,9 & 74,3 & \\
\hline December & 26,8 & 1,1 & & 5,0 & $-0,7$ & & 87,8 & 84,8 & \\
\hline
\end{tabular}

Different forage pea cultivars (Golyazi, Ozkaynak, Taskent, Tore and Urunlu) which are widely cultivated in the district and the population that cultivated in the Ardahan were used as the seed materials.

The experiment was established in the split-plot arrangement within a randomized complete block design with three replications. While the sowing season (autumn and spring) was the main plot, subplots consisted of the genotypes. Sowing was carried out using a $30 \mathrm{~cm}$ rowspacing to the plots consisting of 6 rows at 6 meters long $\left(10.8 \mathrm{~m}^{2}\right)$. Seeds were sown with the experiment drill at a sowing ratio of 100 seeds $\mathrm{m}^{-2}$ (Uzun et al., 2005). As a fertilizer, $150 \mathrm{~kg} \mathrm{ha}^{-1}$ di-ammonium phosphate $(18 \% \mathrm{~N}$, $46 \% \mathrm{P}_{2} \mathrm{O}_{5}$ ) was applied at sowing.

Autumn sowings in the first and second years were completed on 22 October 2014 and 17 October 2015 respectively and the harvest was carried out on 2 June 2015 and 20 May 2016. Spring sowings were completed on 12 March 2015 and 11 March 2016, and the harvest was carried out on 25 and 9 June for 2015 and 2016 respectively. The harvest stage was determined by considering the period from anthesis, the blooming of the plants, to the beginning of pod formation as suggested by Uzun et al. (2005). Plants were harvested by sickle after taking out outer lines of the plots and $50 \mathrm{~cm}$ from the beginning and end of each row. No-irrigation was applied during the experiment and sowings were carried out at the date when the soil moisture was adequate to ensure the germination and emergence.

Plant height was measured before the harvest from 10 plants randomly selected in every plot. Harvested plants were weighed quickly to estimate the fresh forage yield. Fresh samples were oven-dried at $60{ }^{\circ} \mathrm{C}$ until reached constant weight for estimating the dry matter content (Cherney and Marten, 1982). Dry samples were grounded to pass through a $6 \mathrm{~mm}$ sieve and crude protein $(\mathrm{CP})$, neutral detergent fiber (NDF), and acid detergent fiber (ADF) contents were determined using near infra-red spectroscopy (NIRS) (Corson et al., 1999).

Data were subjected to ANOVA using SAS 9.3 statistical software (SAS, 2011) and means were compared using TUKEY Multiple Range Test.

\section{RESULTS}

The average plant height was $104.7 \mathrm{~cm}$ and it did not change significantly between the years and sowing seasons although it changed significantly among the genotypes (Table 2). Tore and Ardahan had the longest $(111.3 \mathrm{~cm}$, 
110.8 respectively) and Urunlu had the shortest plant height $(95.6 \mathrm{~cm})$ among the genotypes (Table 2). While plant height did not show significant differences between the years in terms of autumn sowing, spring-sown plants in the first year had higher plant height than that of the second year (Figure 1). These plant height differences in the spring sowing between the years were responsible for years $\mathrm{x}$ sowing season interaction. Golyazi and Taskent genotypes had higher plant height in the second year, but the other genotypes were higher in the first year. Especially, Urunlu showed serious decreases in plant height in the second year (Figure 2). This different response of plant height to years caused a year $\times$ genotype interaction. Except for Golyazi, the genotypes did not indicate different responses to sowing seasons concerning plant height but spring-sown Golyazi had higher plant height than autumn sowing (Figure 3). This different response to sowing seasons was responsible for sowing season $\times$ genotype interaction. In the experiment, three-way interaction was not significant for plant height.

Table 2. Yield performances of genotypes sown in different seasons and years

\begin{tabular}{|c|c|c|c|}
\hline & Plant height $(\mathrm{cm})$ & Fresh forage yield $\left(\mathrm{t} \mathrm{ha}^{-1}\right)$ & Dry matter yield $\left(\mathrm{t} \mathrm{ha}^{-1}\right)$ \\
\hline \multicolumn{4}{|l|}{ Year $(Y)$} \\
\hline 2015 & 106,8 & $16,90 \mathrm{~b}$ & $3,71 \mathrm{~b}$ \\
\hline 2016 & 102,6 & $20,88 \mathrm{a}$ & $5,39 \mathrm{a}$ \\
\hline \multicolumn{4}{|l|}{ Season (S) } \\
\hline Autumn-sowing & 102,7 & $24,36 \mathrm{a}$ & $5,73 \mathrm{a}$ \\
\hline Spring-sowing & 106,7 & $13,42 \mathrm{~b}$ & $3,36 \mathrm{~b}$ \\
\hline \multicolumn{4}{|l|}{ Genotype (G) } \\
\hline Ardahan pop. & $110,8 \mathrm{a}$ & $22,52 \mathrm{a}$ & $5,09 \mathrm{a}$ \\
\hline Golyazi & $98,2 \mathrm{bc}$ & $14,63 \mathrm{~b}$ & $3,76 \mathrm{c}$ \\
\hline Ozkaynak & $108,8 \mathrm{ab}$ & $20,79 \mathrm{a}$ & $4,56 \mathrm{abc}$ \\
\hline Taskent & $103,6 \mathrm{ab}$ & $19,92 \mathrm{a}$ & $5,04 \mathrm{a}$ \\
\hline Tore & $111,3 \mathrm{a}$ & $20,66 \mathrm{a}$ & $4,80 \mathrm{ab}$ \\
\hline Urunlu & $95,6 \mathrm{c}$ & $14,81 \mathrm{~b}$ & $4,04 \mathrm{bc}$ \\
\hline Mean & 104,7 & 18,89 & 4,55 \\
\hline $\mathrm{Y}$ & ns & $*$ & $*$ \\
\hline $\mathrm{S}$ & ns & $* *$ & $* *$ \\
\hline $\mathrm{G}$ & $* *$ & $* *$ & $* *$ \\
\hline $\mathrm{Y} \times \mathrm{S}$ & $* *$ & $*$ & $*$ \\
\hline$Y \times G$ & $*$ & $* *$ & $*$ \\
\hline$S \times G$ & $*$ & $* *$ & ns \\
\hline$Y \times S \times G$ & ns & $*$ & $* *$ \\
\hline
\end{tabular}

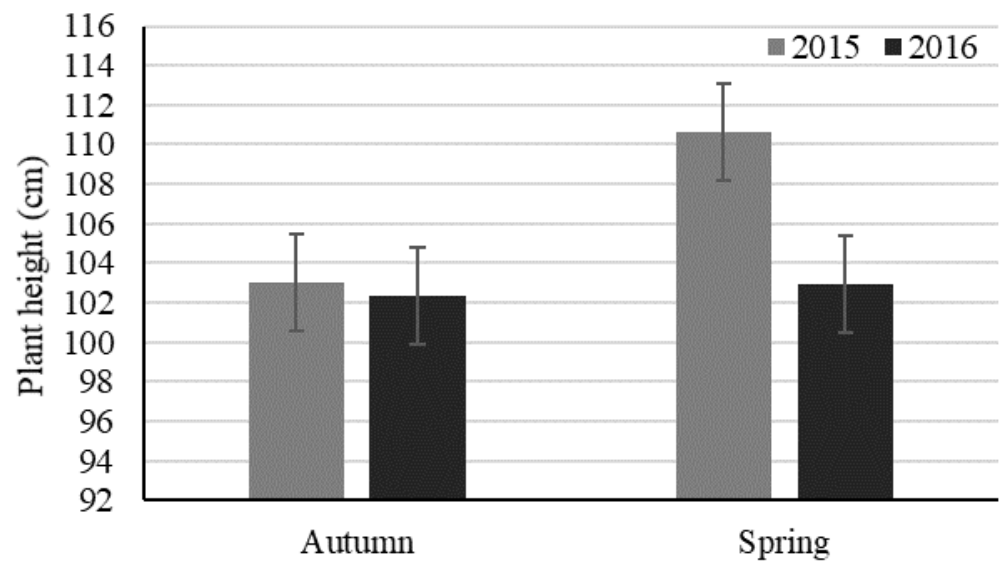

Figure 1. Year x season interaction for plant height 


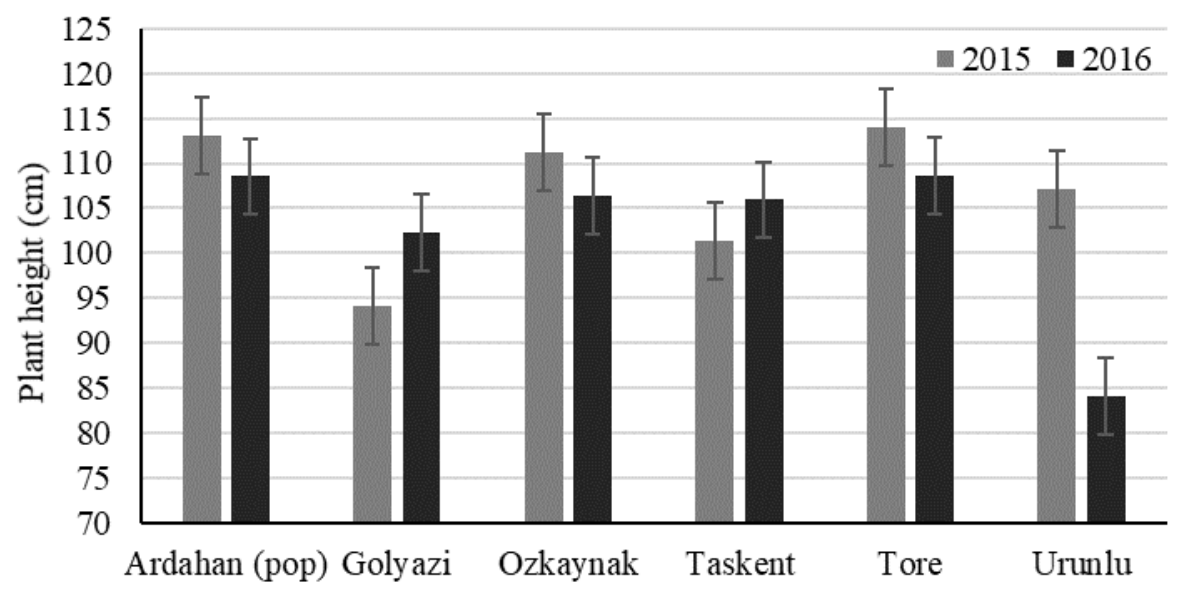

Figure 2. Year x genotype interaction for plant height

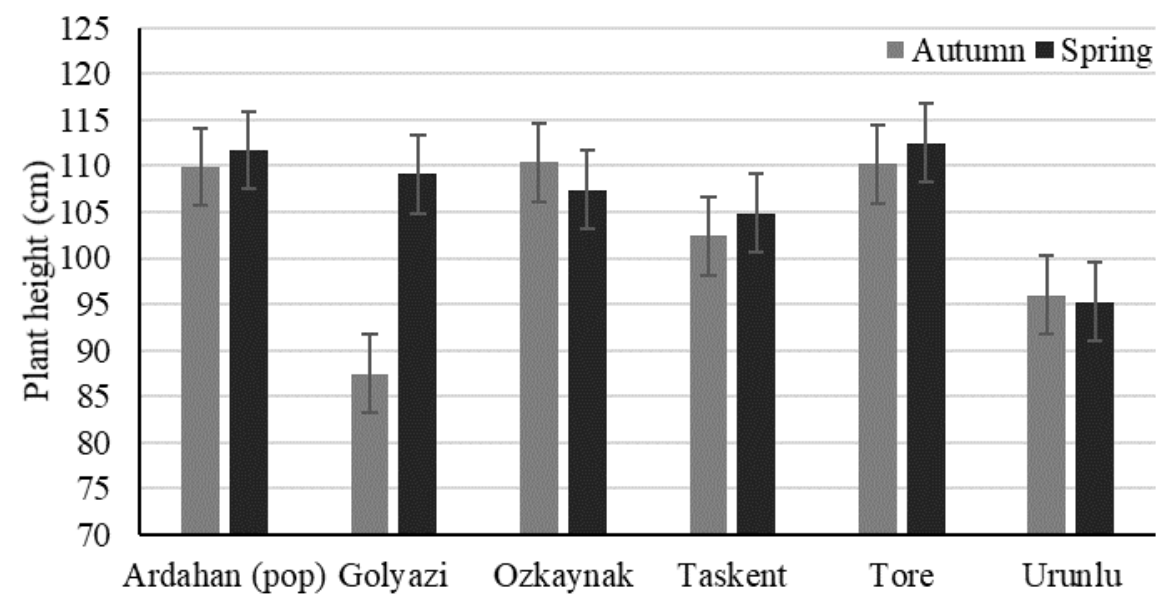

Figure 3. Season $\mathrm{x}$ genotype interaction for plant height

Fresh forage yield variation was significant between the years $(P \leq 0.05)$, sowing seasons $(P \leq 0.01)$, and genotypes $(\mathrm{P} \leq 0.01)$ and three-way interaction were also significant $(\mathrm{p}<0.05)$. The average fresh forage yield was $18.89 \mathrm{t} \mathrm{ha}^{-1}$ and it was higher in $2016\left(20.88 \mathrm{t} \mathrm{ha}^{-1}\right)$ than in 2015 (16.90 $\mathrm{t} \mathrm{ha}^{-1}$ ) (Table 2). Fresh forage yield in spring sowing was quite lower (13.42 $\left.\mathrm{t} \mathrm{ha}^{-1}\right)$ in comparison with autumn sowing (24.36 t ha-1). Among genotypes, Golyazi and Urunlu showed lower yield performances than the other genotypes (Table 2). The yield performance of the genotypes showed a different response to years and sowing season. For example, in the first year, the Ardahan population showed the best performance. The yield performances of Ardahan, Ozkaynak, Taskent, and Tore were stable and higher than the other genotypes in autumn sowing in both years while Golyazi showed a great yield performance variation between the years. Spring-sown genotypes showed different fresh forage yield performance in the first year but they have similar yield performance in the second year. In both years, autumn sowing showed higher yield performance than spring sowing but the dimension of the yield performance difference between sowing seasons was higher in the first year than that of the second year. These different trends caused significant three-way interaction (Figure 4).

The dry matter yield, as in fresh forage yield, significantly varied between years $(\mathrm{P} \leq 0.05)$, sowing seasons $(P \leq 0.01)$, and genotypes $(P \leq 0.01)$, and three-way interaction was also significant $(\mathrm{P} \leq 0.01)$. The average dry matter yield was $4.55 \mathrm{t} \mathrm{ha}^{-1}$ and it was higher in 2016 (5.39 $\left.\mathrm{t} \mathrm{ha}^{-1}\right)$ than in $2015\left(3.71 \mathrm{t} \mathrm{ha}^{-1}\right)$. Autumn sowing provided a higher dry matter yield than spring sowing (5.73 and 3.36 $\mathrm{t} \mathrm{ha}^{-1}$ respectively). Although Tore and Ozkaynak genotypes were included statistically in the high yield group, Ardahan and Taskent genotypes showed a better dry matter yield performance (5.09 and $5.04 \mathrm{t} \mathrm{ha}^{-1}$ respectively) than the others. The response of dry matter yield performance of genotypes to year and sowing season was the same with fresh forage yield (Figure 5), and therefore, three-way interaction was also significant (Table 2). 


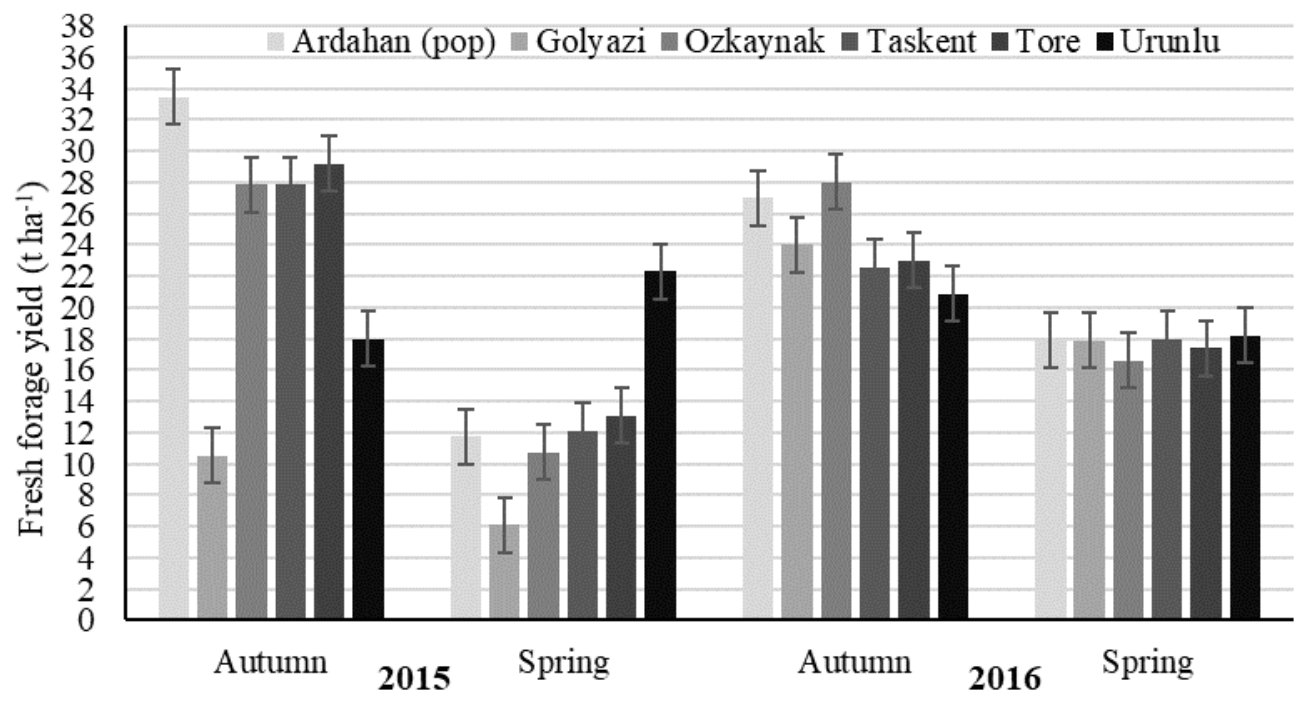

Figure 4. Three-way interaction for fresh forage yield

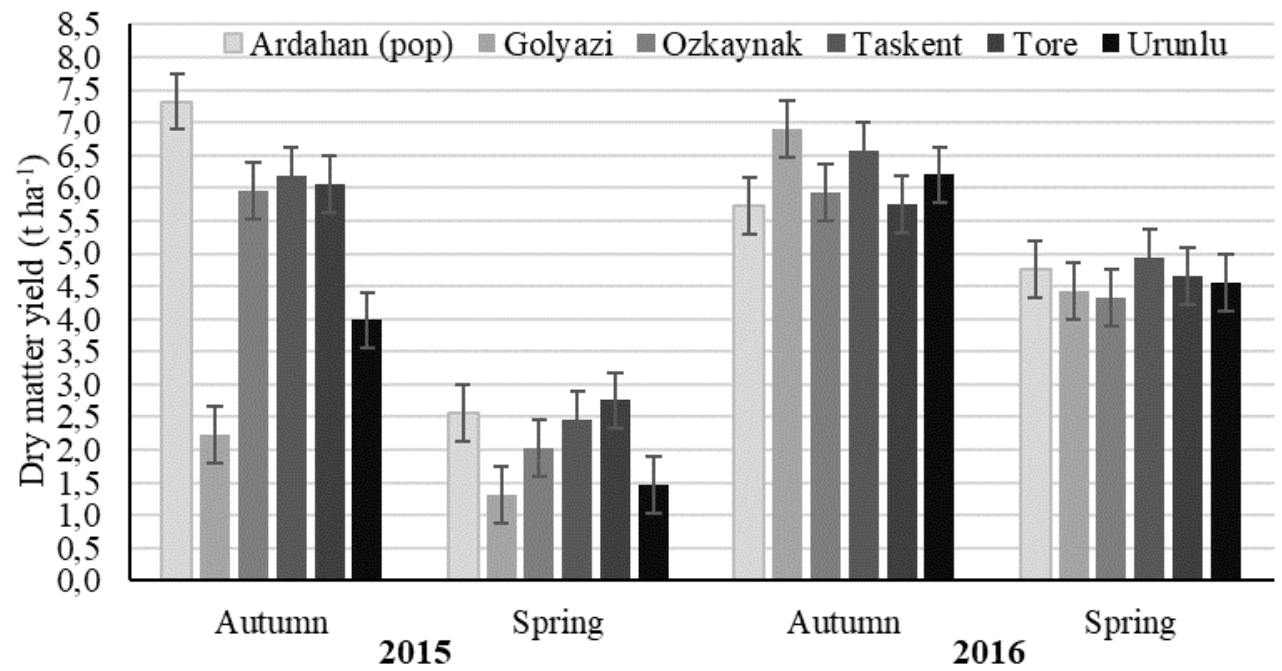

Figure 5. Three-way interaction for dry matter yield

The difference of crude protein content between the years was not significant while it was statistically significant between the seasons and among the genotypes, and the three-way interaction was also significant $(\mathrm{P} \leq 0.01)$. The average crude protein content was $19.84 \%$ and it was higher at autumn sowing $(21.17 \%)$ than spring sowing $(18.53 \%)$. Ozkaynak had the highest crude protein content $(21.53 \%)$ but the difference between Ozkaynak and Urunlu $(20.98 \%)$ was not statistically significant (Table 3$)$. These two cultivars had higher values for both autumn and spring sowing of 2015. Nevertheless, in 2016, Taskent and Urunlu had the highest CP content in autumn and Golyazi and Ozkaynak had higher values in spring (Figure 6). Ardahan population had the lowest crude protein content at $18.26 \%$ and this was due to very low value in spring sowing of 2016 as seen in Figure 6.
There was not a statistically significant difference in NDF content between the years, but it changed significantly $(\mathrm{P} \leq 0.05)$ depending on the seasons and genotypes (Table $3)$. Interactions of year $x$ genotype and season $x$ genotype were statically significant $(\mathrm{P} \leq 0.05)$. The average NDF content was $35.92 \%$ and it was higher at spring sowing (Table 3). Taskent had the highest NDF content $(37.60 \%)$ while Golyazi had the lowest value and the rest of the genotypes did not vary significantly (Table 3 ). Tore had quite higher NDF content in 2015 but in 2016, the highest value was observed in Taskent (Figure 7). NDF content of Taskent was also higher for autumn sowing but, Tore contained relatively higher NDF in spring sowing (Figure 8). 
Table 3. Forage quality of genotypes sown in different seasons and years

\begin{tabular}{lccc}
\hline & CP (\%) & NDF (\%) & ADF (\%) \\
\hline Year (Y) & & & \\
\hline 2015 & 20,37 & 35,57 & 32,89 \\
2016 & 19,33 & 36,28 & 32,78 \\
\hline Season (S) & & & \\
\hline Autumn-sowing & $21,17 \mathrm{a}$ & $34,23 \mathrm{~b}$ & 32,55 \\
Spring-sowing & $18,53 \mathrm{~b}$ & $37,62 \mathrm{a}$ & 33,12 \\
\hline Genotype (G) & & & \\
\hline Ardahan pop. & $18,26 \mathrm{~d}$ & $36,02 \mathrm{ab}$ & $33,29 \mathrm{ab}$ \\
Golyazi & $19,50 \mathrm{bc}$ & $34,06 \mathrm{~b}$ & $31,62 \mathrm{~b}$ \\
Ozkaynak & $21,53 \mathrm{a}$ & $36,79 \mathrm{ab}$ & $33,23 \mathrm{ab}$ \\
Taskent & $19,55 \mathrm{bc}$ & $37,60 \mathrm{a}$ & $33,41 \mathrm{a}$ \\
Tore & $19,25 \mathrm{~cd}$ & $35,37 \mathrm{ab}$ & $32,78 \mathrm{ab}$ \\
Urunlu & $20,98 \mathrm{ab}$ & $35,71 \mathrm{ab}$ & $32,69 \mathrm{ab}$ \\
\hline Mean & 19,84 & 35,92 & 32,83 \\
\hline Y & $\mathrm{ns}$ & $\mathrm{ns}$ & $\mathrm{ns}$ \\
S & $* *$ & $*$ & $\mathrm{~ns}$ \\
G & $* *$ & $*$ & $*$ \\
Y x S & $* *$ & $\mathrm{~ns}$ & $\mathrm{~ns}$ \\
Y x G & $* *$ & $*$ & $\mathrm{~ns}$ \\
S x G & $* *$ & $*$ & $*$ \\
Y x S x G & $* *$ & $\mathrm{~ns}$ & $*$ \\
\hline & & &
\end{tabular}

ADF content was not significant between years and seasons, but the variance among the genotypes and threeway interaction was significant $(\mathrm{P} \leq 0.05)$. ADF was 32.83 $\%$ on average and it was the highest in Taskent (33.41\%) while it was the lowest in Golyazi (31.62 \%). ADF difference was generally low among the genotypes but at the spring sowing of 2016, Golyazi and Urunlu had quite lower values (Figure 9).

\section{DISCUSSION}

In the study, there was not any significant difference in plant height between the years, but in 2015, spring-sown plants were higher than autumn-sown (Figure 1). The height of plants generally increases under favorable environmental conditions and there is a positive linear relationship between the height and yield of forage crops (Sayar and Anlarsal, 2008; Karayel and Bozoglu, 2012). Cool and moisty spring conditions extended the vegetative period in 2015 (Table 1), therefore, forage pea plants, which are typically cool-season plants (McMurray et al., 2011; Liu et al., 2019), showed better growth performance. Consequently, the plants sown in the spring in 2015 had higher plant height. Plant height of genotypes varied significantly among each other due to yearly climatic variations as expected (Figure 2). Especially Urunlu was quite short in 2016 and therefore it was possible to state that yearly climatic variations may affect this cultivar more than the others may. Apart from yearly variations, there was not any significant difference in plant height of autumn and spring-sown forage pea genotypes in the study, but Golyazi was shorter than other genotypes in autumn sowing conditions (Figure 3). Some forage pea cultivars could be affected negatively by winter temperatures below $-14,-15$ ${ }^{\circ} \mathrm{C}$ that causes plants to be shorter in response (Murray et al., 1988; Acikgoz, 2001; Konuk and Tamkoc, 2018). This might be a negative sign for the Golyazi to cultivate under winter conditions of Central Anatolia.

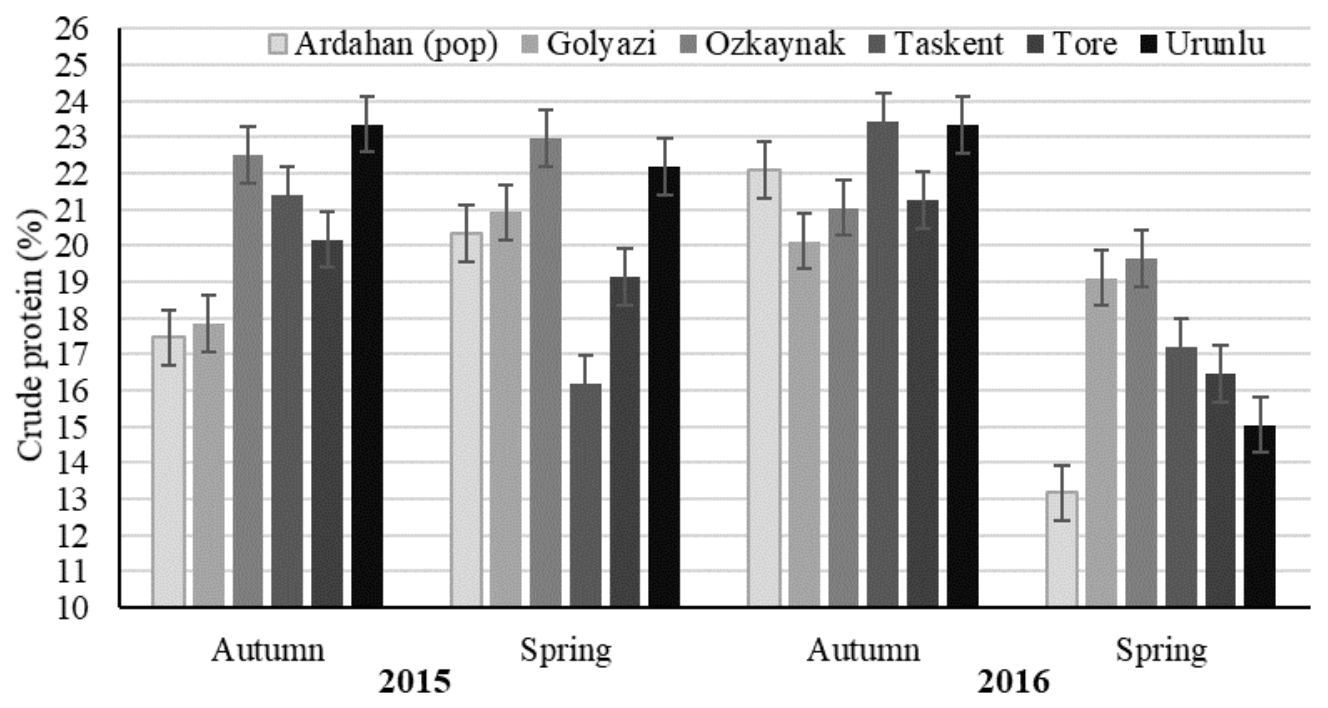

Figure 6. Three-way interaction for crude protein content 


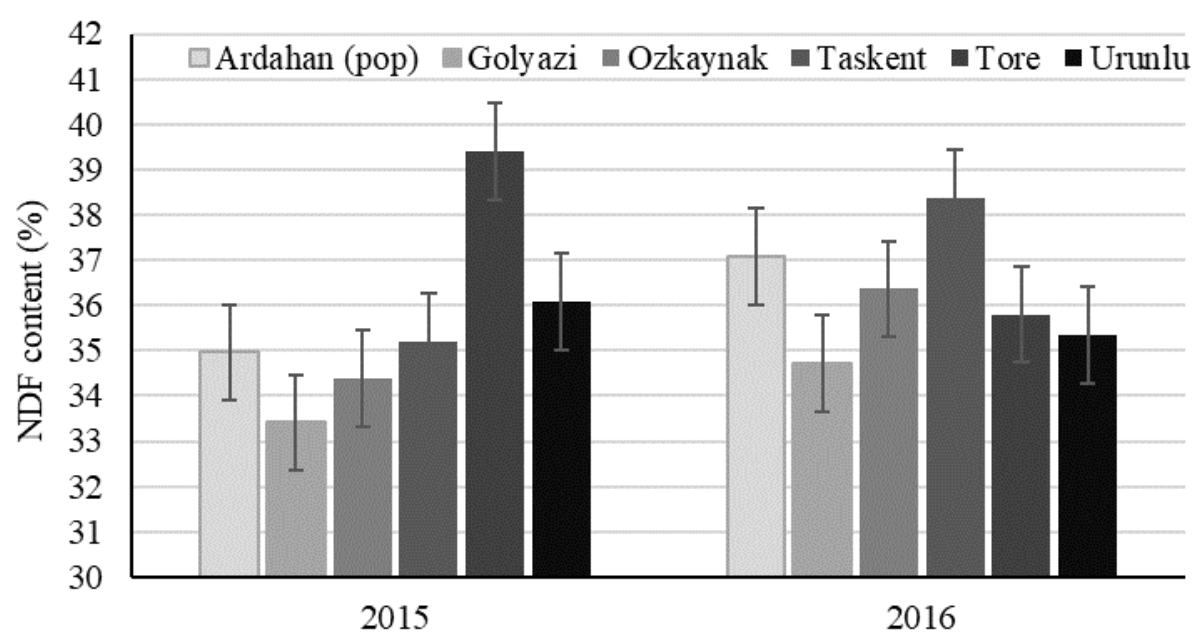

Figure 7. Year $\mathrm{x}$ genotype interaction for NDF content

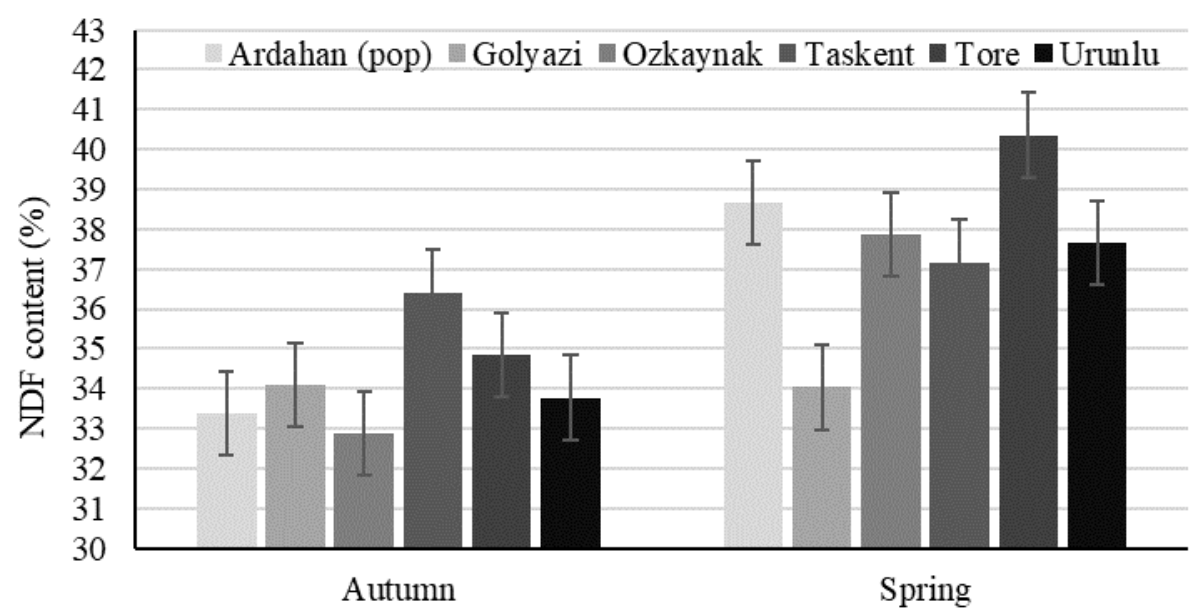

Figure 8. Season x genotype interaction for NDF content

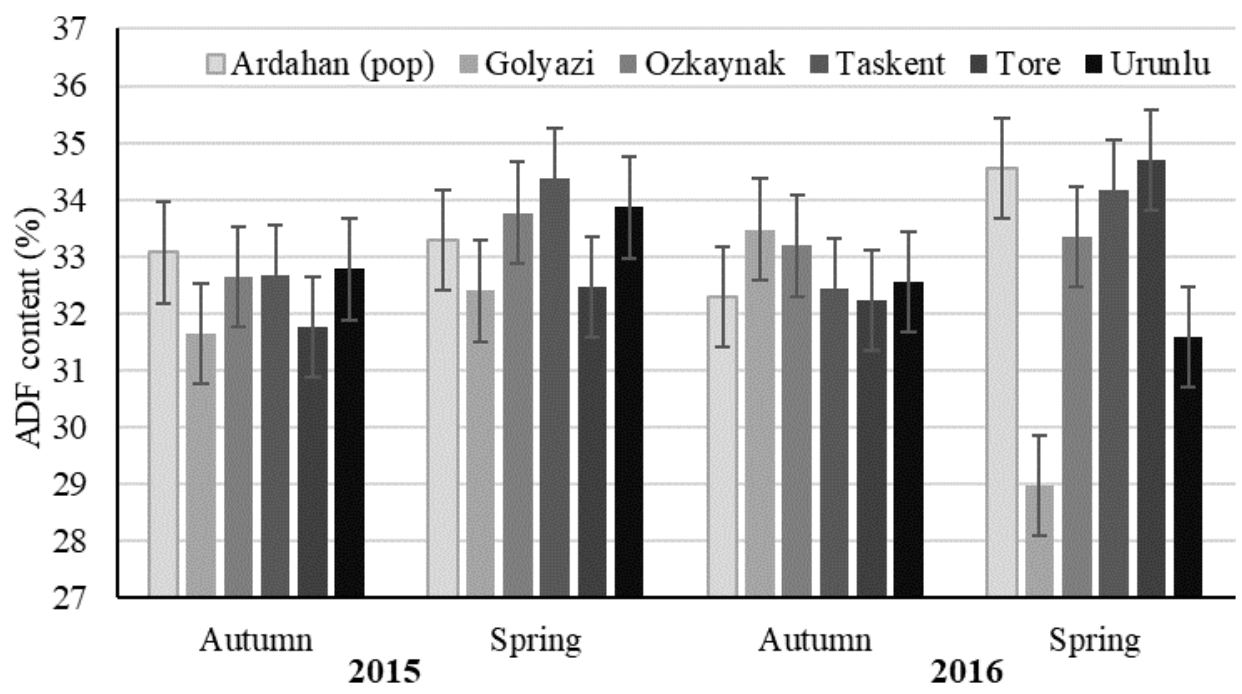

Figure 9. Three-way interaction for ADF content

Forage pea produces more biomass in the years that receive higher precipitation and temperature rises gradually in the spring (Uzun et al., 2005). Higher fresh forage and dry matter yields in the second year of the study are possibly related to higher precipitation, especially received in the winter, which is stored in the soil after the growing period, and gradual temperature rise in the spring of the year (Table 1). Autumn-sown plants have a prolonged vegetation period concerning spring-sown, and therefore, they could produce more biomass (Hakyemez, 2006; Peksen and Gulumser, 2007; Turan and Sakman, 2019). Thus, fresh forage and dry matter yield were higher at 
autumn sowing in the research (Table 2). Another reason might be the rapid increment of spring temperatures in 2015 (Table 1) that negatively affected the growth of forage pea because of the cool season characteristics of the plant (Acikgoz, 2001). The unexpected increase in the spring temperatures (Table 1) could be the reason for prominent yearly variations in spring sowing (Figure 4). Yearly fresh forage and dry matter yield variations were lower at Golyazi and Urunlu (Figure 4, 5). Moreover, the spring performance of Urunlu was higher especially in 2015 (Figure 4, 5), therefore, this cultivar could be used for spring sowing in Central Anatolia and similar conditions. Various responses to the genotypes under changing environmental conditions result from genetic differences (Konuk and Tamkoc, 2018). Even there was not a significant fresh forage and dry matter yield difference among Ozkaynak, Taskent, Tore (cvs.), and Ardahan (pop.), the yearly yield variance of Ozkaynak was lower especially in autumn sowing (Figure 4). Additionally, it was observed that the Ardahan population could produce more forage under favorable environmental conditions.

In the research, the non-significant crude protein variation between the years might be related to the same maturity levels of the plant during the harvest of both years. Because the harvesting stage significantly affects the crude protein content of forage pea (Uzun et al., 2012). Besides the harvesting stage, differences in temperature, precipitation, and vegetation period, which occur especially between the different growing seasons, could significantly affect the yield and quality parameters as crude protein content (Hakyemez, 2006; Tas, 2011; Konuk and Tamkoc, 2018). In our research, higher crude protein content in autumn sowing was a result of higher precipitation and longer vegetation period (Table 1). It was reported that nitrogen fixation and crude protein content of forage legumes could show a decreasing trend under stress conditions such as drought (Krawutschke et al., 2013). Rapidly increasing temperatures might be caused by drought stress, which results in a lower crude protein content of the plants that are sown in spring, especially due to less nitrogen fixation. Autumn-sown genotypes had higher crude protein content especially in the second year of the study (Figure 6). In 2015, there were not significant crude protein differences between the autumn and spring sowing of some cultivars (Ozkaynak, Tore, Urunlu). Moreover, Ardahan (pop.) and Golyazi (cv.) had higher values in spring sowing of 2015 but in 2016, all genotypes except Golyazi and Ozkaynak had quite lower crude protein content in spring sowing (Figure 6). These various responses of the genotypes should be used to select proper cultivars for autumn or spring sowing in the region.

Plant NDF content is composed of structural carbohydrates like cellulose, hemicellulose, lignin, cutin, silica, and it is an important forage quality characteristic that affects the quantity of the animal product, dry matter consumption, and welfare of animals (Beauchemin, 1996; Collins and Fritz, 2003; Tekce and Gul, 2014). The NDF content of forage pea was reported as $38.27 \%$ (Kocaer and Albayrak, 2012), 41.70\% (Ates, 2012), 37.17\% (Tan et al.,
2013) in the previous studies. Our results were slightly lower than the above-mentioned researches. In the study, NDF contents of the genotypes were not significantly different between the experimental years, but spring-sown plants had higher NDF content (Table 3). The NDF content of legumes, as is the other plants, also shows an increasing trend linearly with the increasing temperature and advanced maturity (Buxton, 1996). This increment is mostly because of the decreasing leaf/stem ratio and becomes more severe especially in spring (Buxton, 1996; Collins and Fritz, 2003). In the research, spring-sown plants were exposed to rapid temperature increment for a longer time than autumnsown plants and therefore, NDF content was higher but Golyazi and Taskent genotypes did not show a great variation between the sowing seasons in terms of NDF content (Figure 8). This may indicate that these cultivars could tolerate rapidly increasing spring temperatures.

The ADF content of the plant which composed of cellulose, lignin, and silica, is stated as the indigestible part of the cell wall and increases with the maturation (Collins and Fritz, 2003; Ozyigit and Bilgen, 2006; Erkovan et al., 2009; Balabanli et al., 2010). The variation of ADF content was not significant between years and sowing seasons (Table 3) possibly due to the samples taken in similar harvesting stage but the genotypes showed a significant variation. The ADF variation of the genotypes was quite similar to the NDF (Table 3) but the response of the genotypes in different years and seasons was highly variable (Figure 9). Therefore, it should be stated that the digestibility of the genotypes was also variable in terms of different years and sowing seasons.

\section{CONCLUSION}

Forage pea could produce higher forage yield in autumn sowing conditions of Eskisehir and similar semi-arid ecologies but year-to-year climatic variations significantly affect the production and quality. According to our results, Ozkaynak, Taskent and Tore (cvs.) are proper to cultivate in the region in terms of forage yield and quality. Ardahan population has a great potential for breeding new cultivars because of the high yield of the genotype.

\section{LITERATURE CITED}

Acikgoz, E. 2001. Forage Crops. VIPAS publication number 58, $584 \mathrm{p}$. Bursa (In Turkish)

Asci, O.O., Z. Acar, Y.K. Arici. 2015. Hay yield, quality traits and interspecies competition of forage pea-triticale mixtures harvested at different stages. Turkish Journal of Field Crops 20(2): 166-173

Ates, E. 2012. The mineral, amino acid and fiber contents and forage yield of field pea (Pisum arvense L.), fiddleneck (Phacelia tanacetifolia Benth.) and their mixtures under dry land conditions in the western Turkey. Romanian Agricultural Research 29: 237-244

Ates, E. and A.S. Tekeli. 2017. The effect of different based fertilizer applications on herbage yield and quality of fodder pea (Pisum arvense L.). Kahramanmaras Sutcu Imam University Journal of Nature Sciences 20: 13-16 (In Turkish)

Atis, A. and S. Acikalin. 2020. Yield, quality and competition properties of grass pea and wheat grown as pure and binary mixture in different plant densities. Turkish Journal of Field Crops 25(1): 18-25 
Balabanli, C., S. Albayrak and O. Yuksel. 2010. Effects of nitrogen, phosphorus and potassium fertilization on the quality and yield of native rangeland. Turkish Journal of Field Crops 15(2): 164-168

Ball, D.M., M. Collins, G.D. Lacefield, N.P. Martin, D.A. Mertens, K.E. Olson, D. Putnam, D. Undersander and M.W. Wolf. 2001. Understanding forage quality. American Farm Bureau Federation Publication 1(01)

Beauchemin, K.A. 1996. Using ADF and NDF in dairy cattle diet formulation - a western Canadian perspective. Animal Feed Science and Technology 58(1-2): 101-111

Bilgili, U., U. Aysen, M. Sincik, M. Yavuz, B. Aydinoglu, S. Cakmakci, H. Geren, R. Avcioglu, I. Nizam, A.S. Tekeli, I. Gul, E. Anlarsal, C. Yucel, M. Avci, Z. Acar, I. Ayan, A. Ustun and E. Acikgoz. 2010. Forage yield and lodging traits in peas (Pisum sativum L.) with different leaf types. Turkish Journal of Field Crops 15(1): 50-53

Buxton, D.R. 1996. Quality-related characteristics of forages as influenced by plant environment and agronomic factors. Animal Feed Science and Technology 59(1-3): 37-49

Cacan, E., N. Ozbay and K. Kokten. 2016. Determination of germination and emergence performances of some forage pea lines and varieties at different temperatures. Nevsehir Journal of Science and Technology 5: 62-68 (In Turkish)

Cherney, J.H. and G.C. Marten. 1982. Small grain crop forage potential: I. biological and chemical determinants of quality, and yield. Crop Science 22(2): 227-231

Choi, S.H., S.W. Kim, B.Y. Park, B.D. Sang, Y.K. Kim, J.H. Myung and S.N. Hur. 2005. Effects of dietary crude protein level on growth and meat quality of Korean native goats. Journal of Animal Science and Technology 47(5): 783-788

Collins, M. and J.O. Fritz. 2003. Forage quality. In: Forages: An Introduction to Grassland Agriculture (6th ed.), ed. Barnes, R.F., Nelson, C.J., Collins, M. and Moore, K.J., 363-390, Iowa State Press, Ames.

Corson, D.C., G.C. Waghorn, M.J. Ulyatt and J. Lee. 1999. NIRS: Forage analysis and livestock feeding. In Proceedings of the New Zealand Grassland Association, pp. 127-132

Erkovan, H.I., M.K. Gullap, M. Dasci, A. Koc. 2009. Changes in leaf area index, forage quality and above-ground biomass in grazed and un-grazed rangelands of Eastern Anatolia Region. Journal of Agricultural Sciences 15(3): 217-223

Ghorbani, B., T. Ghoorchi, H. Amanlou and S. Zerehdaran. 2010. Effects of using monensin and different levels of crude protein on milk production, blood metabolites and digestion of dairy cows. Asian-Australasian Journal of Animal Sciences 24(1): 65-72

Hakyemez, B.H. 2006. Effect of sowing dates on forage and seed yields in common vetch (Vicia sativa L.). Journal of Agricultural Faculty of Bursa Uludag University 20(1): 47-55 (In Turkish)

Karayel, R. and H. Bozoglu. 2012. Local pea (Pisum sativum L.) genotypes appropriate for forage. Academic Journal of Agriculture 1(2): 83-90 (In Turkish)

Kocer, A. and S. Albayrak. 2012. Determination of forage yield and quality of pea (Pisum sativum L.) mixtures with oat and barley. Turkish Journal of Field Crops 17(1): 96-99

Konuk, A. and A. Tamkoc. 2018. Effect on some agricultural features of winter and summer planting in forage peas. Journal of Bahri Dagdas Crop Research 7(1): 39-50 (In Turkish)

Krawutschke, M., J. Kleen, N. Weiher, R. Loges, F. Taube and M. Gierus. 2013. Changes in crude protein fractions of forage legumes during the spring growth and summer regrowth period. The Journal of Agricultural Science 151(1): 72-90
Liu, N., C. Karunakaran, R. Lahlali, T. Warkentin and R.A. Bueckert. 2019. Genotypic and heat stress effects on leaf cuticles of field pea using ATR-FTIR spectroscopy. Planta 249(2): 601-613

McMurray, L., J. Davidson, M. Lines, A. Leonforte, M. Salam. 2011. Combining management and breeding advances to improve field pea (Pisum sativum L.) grain yields under changing climatic conditions in southeastern Australia. Euphytica 180: 69-88

Murray, G.A., D. Eser, L.V. Gusta, G. Ete've'. 1988. Winterhardiness in pea, lentil, faba bean and chickpea. In: World Crops: Cool Season Food Legumes ed. Summerfield, R.J., 831-843, Kluwer Academic Publishers, Dordrecht.

Ozyigit, Y. and M. Bilgen. 2006. Effect of different cutting stages on some quality factors in various legume forage crops. Mediterranean Agricultural Sciences 19(1): 29-34 (In Turkish)

Peksen, E. and A. Gulumser. 2007. Comparison of faba bean (Vicia faba L.) genotypes sown in autumn and spring for some plant characters and seed yield. Anadolu Journal of Agricultural Sciences 22(1): 79-85 (In Turkish)

SAS Institute Inc. 2011. Base SAS 9.3 Procedures Guide [computer program], $536 \mathrm{p}$.

Sayar, M.S. and A.E. Anlarsal. 2008. A research on determination of yield and some yield components of forage pea (Pisum arvense L.) cultivars and lines in Diyarbakir ecological conditions. Journal of Cukurova University Institute of Natural and Applied Sciences 17(4): 78-88 (In Turkish)

Tan, M., A. Koc, Z. Dumlu Gul, E. Elkoca, I. Gul. 2013. Determination of dry matter yield and yield components of local forage pea (Pisum sativum ssp. arvense L.) ecotypes. Journal of Agricultural Sciences 19: 289-296.

Tan, M., K.K. Kirci and Z.D. Gul. 2014. Effects of row spacing and seeding rate on hay and seed yield of Eastern Anatolian forage pea (Pisum sativum ssp. arvense L.) ecotype. Turkish Journal of Field Crops 19(1): 96-100

Tas, N. 2011. The effect of optimum mixture type and rate, and cutting time on hay yield and yield components for vetch+wheat mixtures sown in spring and autumn under rainfed conditions. Anadolu Journal of Aegean Agricultural Research Institute 21(1): 1-15 (In Turkish)

Tekce, E. and M. Gul. 2014. The Importance of NDF and ADF in Ruminant Nutrition. Ataturk University Journal of Veterinary Sciences 9(1): 63-73 (In Turkish)

Turan, N. and H. Sakman. 2019. Determination of herbage yield and quality of some Narbon vetch (Vicia narbonensis L.) varieties grown under semi-arid climatic conditions during spring sowing. Anadolu Journal of Agricultural Sciences 34(3): 377-385 (In Turkish)

TUIK, 2019. Crop Production Statistics, Turkish Statistical Institute,

Ankara, https://data.tuik.gov.tr/Kategori/GetKategori?p=tarim111\&dil=2 (Accessed December 20, 2020).

Uzun, A., U. Bilgili, M. Sincik, I. Filya and E. Acikgoz. 2005. Yield and quality of forage type pea lines of contrasting leaf types. European Journal of Agronomy 22(1): 85-94

Uzun, A., H. Gun and E. Acikgoz. 2012. Yield and quality characteristics of some pea (Pisum sativum L.) varieties harvested at different growing stages. Journal of Agricultural Faculty of Bursa Uludag University 26(1): 27-38 (In Turkish)

Yavuz, T. 2017. The effects of different cutting stages on forage yield and quality in pea (Pisum sativum L.) and oat (Avena sativa L.) mixtures. Journal of Central Research Institute for Field Crops 26(1): 67-74 (In Turkish). 